forming the connecting link of a sentence must have been dropped. What I intended to say, without the slightest notion of giving a "technical or scientific" opinion, was, "The iron is alloyed in crucibles, formed with certain clays and a preparation of plumbago." The words italicised disappeared in some mys. terious way. The next of my idiotic sentences goes on to talk about the crucibles, or "creusets," as, to the great scandal of $\mathrm{Mr}$. Forbes, I ventured to call them. If I could stop here, an humble apology for my fault might, perhaps, serve my purpose, but, alas! I have more to answer for. Vaguely dreaming of the foot-pound, I actually zorote kilometre for kilogrammetre, when speaking of the power of the new steam hammer; and, worst of all, I also wrote "Sheffield Gun Metal."

Can I ever hope to be forgiven when thus I write myself down an ass?

Medicus

P.S, - As to the question whether Krupp invented the process employed at his factory, I offer no opinion "scientific" or ordinary. I only repeat the impression which prevails.

\section{FURTHER NOTES ON CERATODUS}

SINCE the article on Ceratodus (published in NATURE, Nos. 99 and 100), was written I have examined a mature female, transmitted, with other examples, by the Trustees of the Sydney Museum to the National Collection, and am enabled to make the following additions:-

I. The oviduct in its developed conditions is, with regard to its internal structure, surprisingly similar to that of Menopoma.

2. The ova are expelled through the oviduct, and not through the peritoneal slits; they receive in the oviduct a coating of an albuminous substance as in Batrachians.

3. The caudal termination of the vertebral column is subject to individual variation. In one example the neural and hæmal elements are continued far beyond the notochord, and are confluent into a tapering band, which is segmented, as is the case in some specimens of Dipterus or Ctenodus.

AlBERT GÜNTHER

\section{ON THE BENDING OF GLACIER ICE *}

$\mathrm{M}$

R. MATTHEWS and Mr. Froude had supported long 1 rectangles of ordinary ice at the two ends, weighted them in the centre, and thus caused them to bend. The ice employed, if I recollect right, was of a temperature some degrees below the freezing point, and in my little Alpine book recently published I expressed a hope that similar experiments might be made with glacier ice. I have been trying my hand at such experiments. The ice first employed was from the end of the Morteratsch Glacier, and when cut appeared clear and continuous. A little exposure, however, showed it to be disintegrated, being composed of those curious jointed polyhedra into which glacier ice generally resolves itself when yielding to warmth. Still, when properly supported and weighted, a long stout rectangle of such ice showed, after twelve hours, signs of bending.

I afterwards resorted to the ice of the sand cones, which, as you know, is unusually frm. From it rectangles were taken from three to four feet long, about six inches wide, and four inches deep. Supported and weighted for a considerable time, no satisfactory evidence of bending appeared; the bars broke before any decided bending took place. Smaller bars were then employed. Two of these were placed across the mouth of an open square box, their ends being supported by the sides of the box. They formed a cross, and a clear interval of at least an eighth of an inch existed between them where they crossed. The upper one was carefully weighted with a block of ice; after two hours it had sunk down. and

* The following is an extract from a note addressed to Prof. Hirst, and sent from Pontresina in the hope that it would reach Edinburgh in sufficient time to be communicated to Section A of the British Association. It was a few hours too lato. - J. T. was found frozen to the under one. They were then separated, and one of them was allowed to remain supported at the ends and weighted by ice at the middle. In a few hours it had bent into a curve, the versed sine of which from a chord uniting the two ends was, at least two inches. In fact, when the rectangles are thin, and the weight carefully laid on, flexure commences very soon, and may by cautious manipulation be rendered very considerable. I think $\mathrm{Mr}$. Froude told me that in his experiment the molecules were "in torture," and that they in great part recovered their positions when the weight was removed. In the foregoing experiments the flexure was permanent.

I tried to bend the rectangle just referred to back again by reversing its position and weighting it with the same block of ice. But whether owing to my want of delicacy in putting on the weight, or through the intrinsic brittleness of the substance itself, it snapped sharply asunder.

I left in your hands when quitting London an exceedingly interesting paper by Prof. Bianconi, in which are figured the results of various experiments on the bending of, I think, lake ice. The foregoing experiments on glacier ice confirm his results.

August 4 JOHN TYNDALL,

I may add that various experiments were subsequently made, and a means discovered of rendering the bending very speedily visible. I hope before long to return to the subject.-J. T., September 28

\section{THE MIGRATION OF QUAIL}

THE fact of this little bird having visited England this year in such numbers appears to have attracted the attention of naturalists as well as sportsmen. In the columns of the Field may be found a census giving particulars of this migration. And it will appear a curious coincidence when I mention that there has been here a greater migration of quail this year than ever remembered before. Where they come from is somewhat mysterious. They have been shot in hundreds in some paddocks, and found as numerous as ever in ten days. I can only account for it by stating that it has been a most remarkable year for grass, and consequently cover was good; and this does not appear conclusive, for the grass has been good all over the country for hundreds of miles towards the north, from which direction some appear to think they come. They are found generally in paddocks, where thistles grow. Can there be any common cause affecting these facts?

Melbourne, August ro

AUSTRAL-ALPINE

\section{FARDIN D'ESSAI, ALGER}

$\mathrm{N} 1832$ the then French Government conceived the idea of forming near the town of Algiers a botanical garden, in which all plants likely to be easily grown in Algeria, and which might be useful either for their ornamentation, or from their economic value, should be kept for distribution or for sale. A portion of ground situated between the sea and the public road, and occupying the place of an old hamma or marsh, was selected for this purpose, which is about two miles from the town. In 1867 the Emperor of the French conceded this establishment to the "Société Générale Algérienne," under whose auspices, but under the direct superintenderice of $M$. Auguste Rivière, the gardens at present are.

In addition to the level swamp, the gardens now also occupy the slope of a low hill on the opposite side of the road. The level ground is laid out in alleys which open out into a circular boulevard which surrounds the whole garden. Carriages are admitted to the circular drive only, foot passengers to the cross walks. A stream of fresh water runs through the grounds, forming in one place a small lake. 
One fresh from the Botanical Gardens of Europe is astonished at every step taken in the Gardens by the wondrous vegetation which is shown by all the semitropical plants. Descending a few steps from the circular drive, a great palm avenue is entered. This avenue was planted in 1847 , and is formed of about eighty trees of the date palm, nearly as many of the Latania Borbonica, and about 150 of the dragon's blood tree (Dracena draco). The avenue is about ten yards wide, and between every two of the date palms there are two of the dragon's blood tree and one Latania. It terminates in a clump of palm trees which are planted almost to the border of the sea. When it is borne in mind that the date palms are from twenty to fifty feet high, the Latanias averaging about twelve, and the Dracrenas about eight feet in height, the general effect of this splendid avenue may be imagined. All the trees were in December last in full flower or fruit, the golden trusses of the date palm contrasting well with the more brightly-coloured clusters of Latania berries. It would require more space than is at our disposal to describe the contents of all the various small avenues that branch off from the main one. The most remarkable smaller avenues are, perhaps, the one formed of bamboo (Bambusa arundinacea), planted in 1863 , and forming an immense mass of foljage, the stems supporting which are from forty to fifty feet high, and that formed of about Ioo plants of Chamcrops excelsa, each about ten feet in height. But remarkable as are these charming subtropical alleys, the visitor is more than surprised when on going towards the portion of the garden where the plants are grouped somewhat according to their natural orders, he finds specimens fifteen feet high of Caryota urens and C. Cumingii, growing with vigour and covered with fruit; of. Oreodoxa regia, from Cuba; several plants upwards of twenty-five feet in height; and a plant of Fubaa spectabilis, which is twelve feet high; and then just a few steps more and a parterre alloted to the natural family of the Musaceæ comes to view. As both the plantain and banana are grown in large quantities for their fruit in another portion of the grounds, the family is here chiefly represented by such genera as Strelitzia and Ravenalia. Magnificent specimens of the latter genus, with stems nine to ten feet high, exhibited great combs of flowers. We are not aware if the Traveller's tree has flowered in Europe, and we were not prepared to find it in full flower in Algiers. It has not, however, matured its fruit in this garden. Near this grand parterre stood another with many fine specimens of Yucca, also a magnificent plot of Aralias, $A$. papyrifera, in full fruit and very handsome; the fine $A$. leptophylla and $A$. pramorsa, thickly covered with spines, and the very ornamental $A$. farinifera; and then one's attention is caught by a large tree (Carolinea macrocarpa) from Brazil, with a couple of dozen of its fruit, each as big as a cocoa nut; by a small forest of Anona cherimolia in full fruit, which is nearly as good as that of the closely related species which yields the custard apple. Near these is an immense tree some thirty feet in height, covered with fruit of the Avocado pear (Persea gratissima); and at its feet is a quantity of guava trees (Pisidium Cattleyanum) crowded with its perfectly ripe, large, pear-shaped, golden fruit. Growing up into the trees, and forming numerous and never-ending festoons, were some specimens of Cacti, chiefly species of Cereus. Some of these were of great size, and one specimen, which had completely strangled a plantain tree some twenty-five feet, was said to have been covered in the autumn with 600 to 700 flowers. It must have been a sight worth a long pilgrimage to see.

Enough has been said to show what a surprising number of semi-tropical fruits luxuriate in the beds of this well-watered garden, and we might add many well-known vegetables to the list, as sweet batat, yam, papaw; but all this while we have been writing of the great level portion of the garden. Outside of this, and on the other side of the roadway, there is a small hill, two or three hundred feet in height, which slopes towards the garden and the sea, and is traversed by several ascending walks. This is the New Holland district of the garden, and certainly not the least interesting portion of it. In one section of it are different species of Acacia, many of them large trees, twenty to twenty-five feet in height. Of the Proteaceæ there were magnificent trees; of the genera Banksia, Hakea, and Grevillea, the collection of species was very large, all of them just bursting into masses of bloom. The most important of the trees growing in this corner of the hill was probably Eucalyptus globulus, of which some trees, now about forty feet in height and over four feet asd a half in circumference, were planted in 1862 , and were then only a few inches high. Young well-established seedlings, of about ten inches in height, are sold for 20 . a hundred, and large numbers of them have been planted from time to time throughout Algeria by the French Government. This species grows in Algeria with most surprising rapidity, under very favourable circumstances growing eighteen to nineteen inches in height each month. Its wood appears to be hard, close in the grain, and it is largely used in the construction of quays, bridges, and railways. This tree seems to do so well on the southern side of the Mediterranean that we think its culture ought to be successfully attempted in the south of Spain, in Sardinia, in Sicily, and the southern parts of Italy. In districts subject to heavy winds it requires for some years-owing to its rapid growth-some protection, but in places sufficiently warm for it, it ought to repay well for any little extra care it might be found to need.

Among the few species that we noticed that did not succeed in these gardens, we may mention the Cedrus deodara; but Casuarina equisetifolia was flourishing, and one tree of Araucaria excelsa was about sixty feet in height, and measuring a little over nine feet in circumference at its base.

The object of the Society in keeping up these Gardens is, as we said, to introduce into Algeria all useful and ornamental plants likely to grow there. In addition they grow enormous quantities of young palms and other ornamental plants for exportation to Europe, and some few plants interesting to the botanist for exchange with other establishments. In a place so favoured by nature and so easily accessible to Europe, it would be, we venture to think, well worth the while of the director of these Gardens to considerably enlarge the last portion of the Society's design. How many tropical plants are yet unknown to the large collectors of Europe, and what a vast percentage of deaths occur among the collections sent from the tropics at any season of the year to our shores! But with Gardens like these at Algeria, situated on the sunny side of the Mediterranean, to act as a halfway house, the resources of the Botanical Gardens or establishments of the North would be indefinitely increased. Another purpose for which these Gardens might be made most useful is for forming a collection of specimens of plants or fruits of economic interest. Many of the fruits, stems, \&c., which ripen in these Gardens as easily as cherries or potatoes with us, are not to be seen in some botanical collections, and are not, in Europe at least, to be purchased. How gladly would some botanist buy such as we here refer to if they were on : sale, say at the depôt of the Algerian Society in Paris; and the expense of putting up such in salt and water would $b$. a mere nothing. The same remarks would apply in many cases to portions of the roots of remarkable genera, ani also to flowers. In calling attention to these Gardens, wo venture to suggest these hints to their well-known director and also to that indefatigable botanist who, more tha any other, now represents science in connection with th Algerian Society, Prof. Durando of Algiers.

E. P.W. 